\section{Effect of educational intervention based on the PRECEDE-PROCEED model on preventive behaviors of cutaneous leishmaniasis among housewives}

\author{
O efeito do programa de educação no modelo \\ PRECEDE-PROCEED sobre comportamentos \\ preventivos contra a leishmaniose cutânea \\ entre donas de casa iranianas
}

\author{
El efecto de un programa educacional, basado \\ en el modelo PRECEDE-PROCEED, sobre las \\ conductas de prevención de la leishmaniasis \\ cutánea entre amas de casa
}

\author{
Ali Khani Jeihooni 1 \\ Pooyan Afzali Harsini 2 \\ Seyyed Mansour Kashfi 3 \\ Tayebe Rakhshani 3
}

doi: 10.1590/0102-311X00158818

\begin{abstract}
Leishmaniasis is an endemic disease in Iran. Since education to prevent the disease is important, this study aimed to determine the effect of educational intervention based on the PRECEDE-PROCEED model on preventive behaviors of cutaneous leishmaniosis among housewives. In this quasi-experimental study, 240 housewives under the coverage of health centers, who lived in the endemic area of Mianshahr, Fasa city, Fars Province, Iran in 2016, were selected (120 people for the experimental group and 120 for the control group).

\author{
Correspondence \\ T. Rakhshani \\ Nutrition Research Center, Department of Public Health, Shiraz \\ University of Medical Sciences. \\ shiraz / Fars - 7461686688, Iran. \\ trakhshani@gmail.com \\ 1 Fasa University of Medical Sciences, Fars, Iran. \\ 2 Kermanshah University of Medical Sciences, Kermanshah, \\ Iran.
}

3 Shiraz University of Medical Sciences, Shiraz, Iran.
\end{abstract} The educational intervention for the experimental group was based on the PRECEDE model, which consists of seven 50-60-minute sessions of lectures, group discussions, role playing, practical displays, and video and PowerPoint displays. These sessions addressed the familiarity with cutaneous leishmaniasis and its different types and carriers, methods of preventing and fighting against it, personal protection, sanitation of the environment and drinking water, spraying of sites, use of mosquito nets, etc. Data were collected before educational intervention and three months after educational intervention. The mean age of the experimental group was 39.24 9.12 years and that of the control group was $38.84 \pm 9.28$ years. Three months after the intervention, the experimental group showed a significant increase in knowledge, attitudes, reinforcing factors, enabling factors, and performance compared to the control group. The education based on enabling factors, reinforcing factors, and predisposing factors had a significant effect on the preventive behaviors of cutaneous leishmaniasis among housewives.

Leishmaniais; Health Education; Disease Prevention 


\section{Introduction}

Leishmaniasis is a zoonotic disease that affects humans and some animals such as dogs and mice, and is transmitted by sand flies 1 . It occurs in three types: cutaneous (leishmaniasis), visceral (kala-azar), and mucocutaneous. According to the World Health Organization (WHO), about 12 million people are infected by different types of leishmaniasis in 80 countries. Over $90 \%$ of the cases of cutaneous leishmaniasis take place in Iran, Afghanistan, Syria, Saudi Arabia, Brazil, and Peru 2. According to the reports by the WHO, the disease is associated with an incidence of six major parasitic diseases in tropical areas 3 . Cutaneous leishmaniasis is a self-limiting disease, but because of its long development period, which leaves scar tissues and damages nearby organs such as ears and noses, it must be treated. Moreover, the disease becomes chronic in $10 \%$ of the cases ${ }^{4}$. Studies have shown that the increase in cutaneous leishmaniosis incidence is attributed to new settlements, urbanization, agricultural development, migration, improvement of reporting systems, and ecological changes 5,6,7,8.

Iran is a country in the Eastern Mediterranean region, where the prevalence of leishmaniasis is high. It is one of the first six countries in the world with the highest prevalence of the disease, and every year about 30,000 cases of cutaneous leishmaniasis are reported 9,10. Generally, some provinces such as Fars, Bushehr, Khorasan, Yazd, Ilam, Khuzestan, and Esfahan have the highest incidence of the disease in Iran 11,12,13. In 1992, cutaneous leishmaniasis became epidemic in the city of Fasa. Statistics show that the number of affected people in Mianshahr is the highest of Fasa 14. The lack of vaccines and drugs for many parasitic diseases such as cutaneous leishmaniasis and the high prevalence of these diseases have made health education a priority for the WHO, in an effort to prevent them 15 .

Training and raising the awareness and skills of people for protecting themselves in endemic areas is one of the best strategies for controlling cutaneous leishmaniasis. The focus of comprehensive health care programs should be on self-care and education rather than treatment and reliance. In addition, effort should be made to enhance the individuals' capabilities for improvement, ability, independence, and non-reliance 7,16,17.

Health promotion is related to all the factors affecting health, including health services, genetic factors, individual behaviors, and socioeconomic and physical environments. For successful implementation of health education and health promotion programs, using theories/models is essential 18,19.

As the map of the educational process, theories/models provide some essential guidelines for educational investigations and diagnosis as well as the methods of educational planning and intervention design, facilitating evaluation. One of these models is the PRECEDE-PROCEED model which is a framework for behavior change that examines the probable outcome of health programs 20 .

PRECEDE is an acronym for Predisposing, Reinforcing and Enabling Constructs in Educational/ Environmental Diagnosis and Evaluation, and PROCEED stands for Policy, Regulatory and Organizational Constructs in Educational and Environmental Development 21.

The model, designed by Lawrence Green and Marshall Crowther, is an approach to planning that analyzes the factors affecting behavior change, and is based on the principle that sustainable change always occurs voluntarily and is determined by personal motivation towards direct involvement in the process of change 22,23. Several educational interventions have been done using the theories of health education and health promotion to improve the performance of health volunteers and health workers 7,9,24. In the study by Nazari et al. 25, educational intervention based on the PRECEDE model increased the average knowledge, attitude, enabling and reinforcing factors, and behavior of the individuals in the experimental group regarding cutaneous leishmaniasis. The study by Nadrian et al. 26 has shown that the PRECEDE model provided an appropriate conceptual framework for designing an educational program on the prevention of skin cancer for students.

In this interventional study conducted in Mianshahr, Fasa, the third stage of this model was used: enabling factors, reinforcing factors, and predisposing factors. By identifying the enabling factors (availability of resources and skills) and reinforcing factors (influence of others, family and peers) and also by enhancing the predisposing factors (knowledge and attitude), one can help people control their disease. Considering the high prevalence of the disease in Fasa, its great importance, and the major role housewives play in educating and guiding family members, this study aimed to determine the effect of educational intervention based on enabling, predisposing, and reinforcing factors on the preventive behaviors of cutaneous leishmaniasis among housewives. 


\section{Materials and methods}

This is a quasi-experimental investigation performed with 240 housewives from May to October 2016. In this study, among the villages covered by the health center of Mianshahr, Fasa, Fars, Iran (13 villages) that had health homes, two villages were randomly selected (Nasir Abad for the experimental group and Rahim Abad for the control group). The sample size formula was based on the study by Nazari et al. 25, with 120 people selected for the experimental group and 120, for the control group.

\section{Study population}

Housewives under the coverage of health homes were selected. From the list of the households covered by each health home, 120 women were randomly selected (out of 240).

Inclusion criteria: housewives covered by the health home who were willing to participate in the study and had not been diagnosed with cutaneous leishmaniasis.

Exclusion criteria: women with disabilities, diseases, and problems that prevented them from participating in the study; women who were absent in more than one session training; lack of consent to participate in the study.

The data collection tool was a researcher-made questionnaire based on reinforcing, predisposing, and enabling factors according to other studies and articles 7,9,25. The questionnaire consisted of demographic information (age, family size, women's education, family income per month, spouse's education, and sources of information about leishmaniasis), knowledge assessment (26 questions), attitude (10 questions), reinforcing factors (10 questions), enabling factors (14 questions), and behavior or performance (8 questions).

The questions were as follows: 26 multiple-choice questions about knowledge (score 1 for correct answers and 0 for wrong answers), 10 questions about attitude (based on the standard 5-point Likert scale ranging from strongly disagree to strongly agree - the lowest score is 10 and the highest score is 50), 10 questions about reinforcing factors (options in a range of yes, to some extent, or no), 14 questions about enabling factors (in a range of yes, to some extent, or no), and 8 questions about performance (in a range of yes, to some extent, or no). The final score of each structure was set on the basis of 100 .

Before the educational intervention, both experimental and control groups completed the questionnaire. The educational intervention for the experimental group consisted of seven 50-to-60-minute sessions of lectures, group discussions, role playing, practical displays, and video and PowerPoint displays. These sessions addressed the familiarity with cutaneous leishmaniasis and its different types and carriers, methods of preventing and fighting against it, personal protection, sanitation of the environment and drinking water, spraying of sites, use of mosquito nets, etc. To increase the educational outcomes, the housewives were divided into groups of 5-6 collaborators and friends to work together. In one of the educational sessions, in addition to the housewives, family heads were invited to attend the meeting and were trained. An educational session was also held for physicians, health care personnel, health workers, village council, and local dignitaries, and their role in educating people and controlling the disease was emphasized. The educational sessions were held with the help of four public health experts employed in the disease fighting unit of Fasa Health Center and the study researchers.

At the end of the educational sessions, some guidelines were given to participants and contact numbers were provided for direct contacts, to increase the ability of the individuals for prevention and control of the disease. Two following sessions were also held with the interval of one month for the subjects to recall what they had learned and to fix their problems, remove obstacles, and answer their questions. After three months, the questionnaire was completed by both groups. For illiterate people, the questionnaire was completed with the help of the research group. To observe moral considerations, an educational session was held for the control group at the end of the educational program. This research project was approved by the Research Council of Fasa University of Medical Sciences and its Ethics Committee (Ethical code: IR.FUMS.REC.2016.040). The aims and importance of the study were explained to the subjects and their written consent was obtained.

Data analysis was carried out using SPSS version 22 (https://www.ibm.com/). Descriptive statistics was used to describe the characteristics of the subjects and distribution of variables involved in the 
study. Data distribution was normal. Demographic variables of the two groups were compared using chi-square and independent t-test. T-paired test was used to compare the participants mean scores of knowledge, attitude, performance, enabling factors, and reinforcing factors before educational intervention and three months after educational intervention in each group. In addition, independent samples t-test was used to compare knowledge, attitude, performance, enabling factors, and reinforcing factors. Significance was set at $\mathrm{p}<0.05$.

\section{Results}

In this research, 240 housewives were studied. Both the experimental and control groups took part in the investigation from beginning to end and no one abandoned the study. The mean age of the experimental group was $39.24 \pm 9.12$ years and that of the control group was $38.84 \pm 9.28$ years ( $\mathrm{p}=0.151$ ). The average household size of the experimental group was $3.82 \pm 1.30$ people and that of the control group was $3.86 \pm 1.50$ people $(\mathrm{p}=0.814)$. The independent $\mathrm{t}$-test showed no significant difference between the two groups.

The chi-square test showed no significant difference between the experimental and control groups in terms of the following variables: housewives' education level ( $p=0.510)$, spouses' education level ( $\mathrm{p}=0.811)$, husbands' job ( $\mathrm{p}=0.325)$, and family income per month $(\mathrm{p}=0.312)$ (Table 1$)$.

The most important sources of information about leishmaniasis in the experimental group were: health workers ( 35 cases, 29.15\%), relatives and friends (45 cases, 37.50\%), radio and television (20 cases, 16.68\%), books, magazines, and newspapers (10 cases, 8.34\%), and the internet and others (10 cases, 8.34\%). The most important sources of information in the control group were: health workers (42 cases, 35\%), relatives and friends (38 cases, $31.66 \%$ ), radio and television (25 cases, $20.84 \%$ ),

\section{Table 1}

Demographic characteristics of the participants (qualitative variables).

\begin{tabular}{|c|c|c|c|c|c|}
\hline \multirow[t]{2}{*}{ Variable } & \multicolumn{2}{|c|}{ Experimental group } & \multicolumn{2}{|c|}{ Control group } & \multirow[t]{2}{*}{ p-value } \\
\hline & $\mathbf{n}$ & $\%$ & $\mathbf{n}$ & $\%$ & \\
\hline \multicolumn{6}{|l|}{ Education level } \\
\hline Illiterate & 18 & 15.00 & 20 & 16.68 & 0.510 \\
\hline Elementary School & 45 & 37.50 & 42 & 35.00 & \\
\hline Junior High School & 25 & 20.84 & 26 & 21.66 & \\
\hline Senior High School & 26 & 21.66 & 24 & 20.00 & \\
\hline Academic & 6 & 5.00 & 8 & 6.66 & \\
\hline \multicolumn{6}{|l|}{ Income (IRR) } \\
\hline Lower than 5 million & 62 & 51.66 & 55 & 45.83 & 0.312 \\
\hline 5-10 million & 46 & 38.34 & 55 & 45.83 & \\
\hline Higher than 10 million & 12 & 10.00 & 10 & 8.34 & \\
\hline \multicolumn{6}{|l|}{ Husband's education level } \\
\hline Illiterate & 14 & 11.66 & 16 & 13.33 & 0.811 \\
\hline Elementary School & 36 & 30.00 & 32 & 26.66 & \\
\hline Junior High School & 30 & 25.00 & 31 & 25.85 & \\
\hline Senior High School & 25 & 20.84 & 28 & 23.33 & \\
\hline \multicolumn{6}{|l|}{ Husband's job } \\
\hline Employee & 16 & 13.33 & 17 & 14.16 & 0.325 \\
\hline Worker & 21 & 17.50 & 18 & 15.00 & \\
\hline Retired & 8 & 6.66 & 10 & 8.34 & \\
\hline Self-employed & 38 & 31.66 & 35 & 29.16 & \\
\hline Others & 37 & 30.85 & 40 & 33.34 & \\
\hline
\end{tabular}


books, magazines, and newspapers (8 cases, $6.66 \%$ ), and the internet and others (7 cases, 5.84\%). Three months after the intervention, the experimental group showed a significant increase in the knowledge, attitude, reinforcing factors, enabling factors, and performance compared to the control group (Table 2).

\section{Discussion}

The study results indicated the effectiveness of the interventions based on the PRECEDE model to promote preventive behaviors against cutaneous leishmaniasis among the housewives. In this study, the experimental and control groups had no significant difference in terms of demographic characteristics and mean scores of knowledge, attitude, enabling factors, reinforcing factors, and performance before the intervention, with consistent and homogenous data. This indicates the minimal effect of confounding factors on the results of the research. The low level of knowledge in both the control and experimental groups shows that these groups are highly in need of education. In fact, housewives play a major role in training family members and controlling the disease, and knowledge is their primary need to fulfill their duties. Our results have shown that the mean knowledge score increased significantly after the intervention in the experimental group, while no change was found in the control group. Holding educational sessions for housewives, providing them with educational pamphlets, and educating them through group discussions and film screenings increased the their knowledge and positively changed their attitude.

A cross-sectional study conducted by Akram et al. 27 on 250 household with samples collected from five localities including Bhawalpur, Multan, Jhang, Faisalabad, and Lahore has shown that the respondents had a poor knowledge of the vector and disease. Few of the participants were aware about the identification of sand flies, their breeding place, biting time, transmission of leishmaniasis, and control measures.

\section{Table 2}

Comparison between the mean scores of knowledge, attitude, enabling factors, reinforcing factors, and performance of the subjects before and after the educational intervention in the experimental and control groups.

\begin{tabular}{|c|c|c|c|c|}
\hline Variable/Group & Pre-intervention & Post-intervention & Differences & Paired t-test \\
\hline \multicolumn{5}{|l|}{ Knowledge } \\
\hline Experimental & $9.32 \pm 47.32$ & $5.12 \pm 71.32$ & $24.00 \pm 7.14$ & 0.001 \\
\hline Control & $9.12 \pm 45.75$ & $8.75 \pm 47.25$ & $1.50 \pm 7.32$ & 0.080 \\
\hline Independent t-test & 0.541 & 0.001 & & \\
\hline \multicolumn{5}{|l|}{ Attitude } \\
\hline Experimental & $4.15 \pm 33.2$ & $6.14 \pm 59.15$ & $25.95 \pm$ & 0.001 \\
\hline Control & $3.89 \pm 31.45$ & $3.19 \pm 32.35$ & $0.9 \pm 3.56$ & 0.121 \\
\hline Independent t-test & 0.612 & 0.001 & & \\
\hline \multicolumn{5}{|l|}{ Enabling factors } \\
\hline Experimental & $2.25 \pm 28.32$ & $5.12 \pm 69.33$ & $41.01 \pm 3.73$ & 0.001 \\
\hline Control & $2.64 \pm 27.96$ & $2.22 \pm 29.31$ & $1.35 \pm 2.47$ & 0.091 \\
\hline Independent t-test & 0.302 & 0.001 & & \\
\hline \multicolumn{5}{|l|}{ Reinforcing factors } \\
\hline Experimental & $10.06 \pm 33.75$ & $10.55 \pm 61$ & $27.25 \pm 10.29$ & 0.001 \\
\hline Control & $10.66 \pm 32.02$ & $10.76 \pm 33.78$ & $1.76 \pm 10.58$ & 0.622 \\
\hline Independent t-test & 0.810 & 0.001 & & \\
\hline \multicolumn{5}{|l|}{ Performance } \\
\hline Experimental & $4.12 \pm 21.15$ & $6.36 \pm 53.29$ & $32.14 \pm 5.62$ & 0.001 \\
\hline Control & $5.45 \pm 20.32$ & $4.98 \pm 22.61$ & $2.29 \pm 5.27$ & 0.540 \\
\hline Independent t-test & 0.620 & 0.001 & & \\
\hline
\end{tabular}


The study by Hosseini et al. 28 suggested that theory-based educational interventions increased the knowledge of the health volunteers. Kashfi et al. ${ }^{13}$ showed that educational interventions based on the PRECEDE model could promote the knowledge of health workers and the housewives covered by them. In a study conducted by Nazari et al. 25 based on the same model, it was shown that educational interventions could increase the knowledge of the housewives in Kharameh about cutaneous leishmaniasis. The results of this study are consistent with those of other studies 29,30,31. After the educational intervention, a significant increase was observed in the mean score of attitude in the experimental group, and this reflects the effect the PRECEDE model on increasing positive attitude. In the model, predisposing factors such as attitude are prior in behavior and can be considered motivating factors for behavior. In this study, a positive attitude might facilitate the adoption of an appropriate performance by housewives to adopt preventive behaviors against cutaneous leishmaniasis. Group discussion and presenting positive and negative experiences encouraged them to engage in preventive behaviors of leishmaniasis through role playing. To improve the attitude, an educational picture booklet was given to the subjects and motivational messages were sent to them once a week.

A study with 103 respondents from 10 Kani tribal settlements of the Thiruvananthapuram district, in Kerala, India, showed that, although 39.8\% of respondents recognized pictures of cutaneous leishmaniasis shown to them, they did not have any lay perceptions. There was absolutely no awareness on vector, transmission, risk factors, and control measures. The role of sandflies in causing cutaneous leishmaniasis was not known to the residents and this prevented them from using any personal protection and adhering to control measures, which in turn poses risk of spreading the infection within settlements and to newer areas 32 .

The study by Heshmati et al. showed that a model-based educational intervention could increase a free attitude towards cutaneous leishmaniosis 9 . In a study by Matin et al., education based on the PRECEDE model had promoted the elderly's attitudes 33 . The findings of this study are consistent with those of other studies 34,35,36,37.

The results of our study have shown a significant difference between the experimental and control groups in terms of the enabling factors after the intervention. Providing educational booklets for the housewives, contacting and following them up after the educational sessions, increasing the availability of physicians, holding educational sessions for health workers and village council, and showing films increased the empowerment of the housewives to prevent cutaneous leishmaniasis. The results of this study are consistent with those of Hosseini et al. 28, Nazari et al. 25, Khani Jeihooni et al. 38, and Kashfi et al. 30. In the study by Darvishpour \& Heshmati ${ }^{39}$, enabling factors in the PRECEDE model were the most important predictors of nurses' performance in cardiopulmonary resuscitation. The study by Nadrian et al. showed that enabling factors were the most powerful predictors of preventive behaviors against skin cancer among students in Tehran 26.

Our results showed a significant difference between the experimental and control groups in terms of reinforcing factors within three months after the intervention, and this revealed the effect of using the PRECEDE model to increase the reinforcing factors. Holding educational sessions for doctors, health care personnel, health workers, and village council; involving the heads of households as social supporters; providing educational contents by group discussions; and creating groups of collaborators and friends led to an increase in the scores of reinforcing factors in the experimental group. In the study by Nazari et al. 25 , the mean score of reinforcing factors within two months after the intervention showed an increase in the experimental group, but no change in the control group.

In the study carried out by Hazavehei et al. 36, the mean score of subjective norms (reinforcing factors) increased after the educational intervention on diabetes.

In the studies by Kohzadi 40 and Hazavehei \& Hasanzadeh 41, no significant change was observed in subjective norms (reinforcing factors) after the educational intervention. Daboné et al. 42 focused on the effect of reinforcing factors on the food intake of students. Regarding the performance of housewives, this study has shown that, after the educational intervention, the mean score of the experimental group significantly increased, while there was no significant change in the control group. The increase in the performance score of the experimental group shows that knowledge, attitudes, reinforcing factors, and enabling factors had an impact on the performance of the housewives. Given that behavior is a complex phenomenon, any program focused on improving people's health information regardless of reinforcing and enabling factors often fails to change behaviors. In our study, we 
held educational sessions, provided educational booklets, and involved important supporters such as doctors, health care personnel, heads of families, health workers, and local dignitaries as enabling and reinforcing factors. Thus, the housewives' behaviors could be changed.

The results of this study are consistent with those of Nazari et al. ${ }^{25}$, Khani et al. 7 , Hosseini et al. 28 , and Kashfi et al. 30.

\section{Conclusion}

The results of this study have shown that an educational program based on the PRECEDE model was able to change the housewives' behavior. As this model contains the structures of knowledge, attitude, enabling factors, and reinforcing factors, it made the education more effective, resulting in significant changes in the housewives' behavior towards cutaneous leishmaniasis. This model can help planners in the development of health policies and might be an appropriate strategy for empowering people to do more effective interventions in the prevention and control of cutaneous leishmaniasis. The findings of this study can help health planners to carry out proper educational interventions for control of the disease by cooperation with effective individuals and involvement of the people. It is recommended that some workshops are held to make the health centers' staff familiar with health education models and health promotion, so that, by educating health workers, effective steps can be taken to empower families and groups for prevention of the disease. The strengths of this study include: providing community-based educational intervention in an endemic area of cutaneous leishmaniasis, and the relatively large sample size that was studied. One weakness of this study could be the selfreporting of some behaviors.

\section{Contributors}

A. K. Jeihooni contributed in the conception or design of the study. P. A. Harsini contributed in the critical revision of the manuscripty. S. M. Kashfi contributed in the data analysis and interpretation. T. Rakhshani contributed in the data collection. All authors reviewed and approved the final version for publication.

\section{Additional informations}

ORCID: Ali Khani Jeihooni (0000-0003-43343356); Pooyan Afzali Harsini (0000-0003-16896895); Seyyed Mansour Kashfi (0000-0003-22580088); Tayebe Rakhshani (0000-0003-3693-8802).

\section{Acknowledgments}

Our special thanks go to all the women who participated in this project. This study was granted and approved by Fasa University of Medical Sciences, Fasa, Iran.

\section{References}

1. Alemu A, Alemu A, Esmael N, Dessie Y, Hamdu $\mathrm{K}$, Mathewos B. Knowledge, attitude and practices related to visceral leishmaniasis among residents in Addis Zemen town, South Gondar, Northwest Ethiopia. BMC Public Health 2013; 13:382.

2. Vahabi A, Rassi Y, Oshaghi MA, Vahabi B, Rafizadeh S, Sayyad S. First survey on knowledge, Attitude and practice about cutaneous leishmaniasis among dwellers of Musian district, Dehloran County, Southwestern of Iran, 2011. Life Sci J 2013; 10:864-8.

3. Babiker AM, Ravagnan S, Fusaro A, Hassan MM, Bakheit SM, Mukhtar MM, et al. Concomitant infection with Leishmania donovani and L. major in single ulcers of cutaneous leishmaniasis patients from Sudan. J Trop Med 2014; 2014:170859.

4. Alavi-Naini R, Fazaeli A, O’Dempsey T. Topical treatment modalities for old world cutaneous leishmaniasis: a review. Prague Med Rep 2012; 113:105-18.

5. Mohebali M. Visceral leishmaniasis in Iran: review of the epidemiological and clinical features. Iran J Parasitol 2013; 8:348-58.

6. Murray HW, Berman JD, Davies CR, Saravia NG. Advances in leishmaniasis. Lancet 2005; 366:1561-77. 
7. Jeihooni AK, Hatami M, Kashfi SM, Heshmati $\mathrm{H}$. The effectiveness of education based on BASNEF model program in promotion of preventive behavior of leishmaniasis among health workers and families under health centers coverage. Journal of Fasa University of Medical Sciences 2012; 2:26-33.

8. Grangeiro Júnior CRP, Pimentel JVC, Teixeira Júnior AG, Jesus AF, Galvão TCF, Souza LAA, et al. American cutaneous leishmaniasis in a northeast Brazilian city: clinical and epidemiological features. Rev Soc Bras Med Trop 2018; 51:837-42.

9. Heshmati H, Rahaei Z, Hazavehei S, Dehnadi A, Hasanzadeh A. Related factors to educational behaviors of health volunteers about cutaneous leishmaniasis on the basis of BASNEF model in Yazd. Journal of Health 2010; 1:4856.

10. Saberi S, Hejazi SH, Jafari R, Bahadoran M, Akbari M, Soleymanifard S. The cutaneous leishmaniasis reservoirs in Northern Baraan Region of Isfahan, Iran. Journal of Isfahan Medical School 2013; 30:1497-507.

11. Salehi-Moghadam A, Barati M, Dabbagh Mpoghadam A, Khoshdel AR, Hosseini Shokouh SJ, Totonchian M. Temporal changes and mapping Leishmaniasis in military units of I.R.I.Army. Hormozgan Medical Journal 2014; 18:91-8.

12. Sarkari B, Qasem A, Shafaf MR. Knowledge, attitude, and practices related to cutaneous leishmaniasis in an endemic focus of cutaneous leishmaniasis, Southern Iran. Asian Pac J Trop Biomed 2014; 4:566-9.

13. Kashfi SM, Khani Jeihooni A, Rezaeianzade A. Effect of health workers' training programs on preventive behavior of leishmaniosis based on BASNEF model. J Res Health Sci 2012; 12:114-8.

14. Noorpisheh S, Naghizadeh MM, Nikrouz L. A study on the life quality of patients suffering from leishmaniasis. Journal of Fasa University of Medical Sciences 2013; 3:155-62.

15. Massome K, Pashtoon MK, Shah Mohammad M, Igbal T, Talha K. Vector control in cutaneous leishmaniasis of the old world: a review of literature. Dermatol Online J 2008; 14:1.

16. Kishro V, Kumar S, Kesar DS, Dinesh A. Vector control in leishmaniasis. Indian J Med 2006; 123:467-472.

17. Cutler DM, Lleras-Muney A. Understanding differences in health behaviors by education. J Health Econ 2010; 29:1-28.

18. Koelen MA, van den Ban AW. Health education and health promotion. Wageningen: Wageningen Academic Publishers; 2004.

19. Green L, Krauter MW. Health Program planning: an educational and ecological approach. 4th Ed. New York: McGraw-Hill; 2005.

20. Mohammadi N, Rafieifar SH, Akbari M, Jamshidi H. Health education (acquaintance with practical concepts) for health education experts. Ministry of Health \& medical education, health help meeting, operation of communications and health education. Tehran: Mehre Raves/Tehran University of Medical Sciences; 2005.
21. Sharma M, Romas JA. Theoretical foundations of health education and health promotion. 2nd Ed. Burlington: Jones \& Bartlett Learning; 2012.

22. Saffari M, Shojaiezadeh D, Ghofranipour F, Pakpour A, Ramazankhani A, Hosseini Sade SR. Health communication. Tehran: Easar and Sobhan Institute; 2012.

23. Hazavehei SM, Jalili Z, Heydarnia AR, Faghihzadeh S. Application of the PRECEDE model for controlling iron-deficiency anemia among children aged 1-5, Kerman, Iran. Promot Educ 2006; 13:173-7.

24. Rahaei Z, Heshmati H, Hazavehei MM, Hasanzadeh A. Relationship between educational practice of volunteer health workers and preventive behavior of households under their coverage regarding cutaneous leishmaniasis based on the BASNEF model in Yazd City, Iran. Journal of School of Public Health and Inbstitute of Public Health Research 2010; 9:77-85.

25. Nazari M, Taravatmanesh G, Kaveh MH, Soltani A, Ghaem H. The effect of educational intervention on preventive behaviors towards cutaneous leishmaniasis at Kharameh city in 2014. Shiraz E-Medical Journal 2016; 17:e39957

26. Nadrian H, Rahaee Z, Mazloomy Mahmoodabad SS, Bahrevar V, KHajeh Z, Najafi S, et al. Effects of educational intervention on promoting skin cancer preventive behaviors and its predisposing factors among female students in Yazd city: An application of some PRECEDE Model constructs. Razi Journal of Medical Sciences 2014; 21:55-64.

27. Akram A, Khan HA, Qadir A, Sabir AM. A cross-sectional survey of knowledge, attitude and practices related to cutaneous leishmaniasis and sand flies in Punjab, Pakistan. PLoS One 2015; 10:e0130929.

28. Hossieni HS, Jajarmi H, Rajabzadeh R, Marzi Z, Arzamani K, Heshmati H. The effect of educational program based on BASNEF model on Volunteer Health Workers(VHWs) on Preventive behaviors among families under supported of VHWs. Journal of North Khorasan University of Medical Sciences 2015; 7:561-72.

29. Jeihooni AK, Kashfi SM, Hatami M, Avand A, Bazrafshan MR. The effect of educational program based on PRECEDE model in promoting prostate cancer screening in a sample of Iranian men. J Cancer Educ 2017; 34:161-72.

30. Kashfi SM, Khani Jeihooni A, Rezaianzadeh A, Karimi S. The effect of mothers education program based on the precede model on the mean weight in children (6-12 months) at health centers in Shiraz, Fars Province. Med J Islam Repub Iran 2014; 28:95.

31. Khani Jeihooni A, Moradi M. The effect of educational intervention based on PRECEDE Model on promoting skin cancer preventive behaviors in High School students. J Cancer Educ 2018; [Epub ahead of print]. 
32. Nandha B, Srinivasan R, Jambulingam P. Cutaneous leishmaniasis: knowledge, attitude and practices of the inhabitants of the Kani forest tribal settlements of Tiruvananthapuram district, Kerala, India. Health Educ Res 2014; 29:1049-57.

33. Matin H, Rastgarimehr B, Afkari ME, Solhi M, Taghdisi MH, Mansourian M, et al. Relationship between the educational stage of PRECEDE model and quality of life improvement in the elderly affiliated with Tehran culture house for the aged. Iranian Journal of Diabetes and Lipid Disorders 2014; 13:469-78.

34. Zendeh Talab H. The effect of a program designed based on PRECEDE-PROCEED model on adolescents' mental health and their parents' participation. Evidence-based Care Journal 2012; 2:45-54.

35. Dizaji MB, Taghdisi MH, Solhi M, Hoseini SM, Shafieyan Z, Qorbani M, et al. Effects of educational intervention based on PRECEDE model on self care behaviors and control in patients with type 2 diabetes in 2012. J Diabetes Metab Disord 2014; 13:72.

36. Hazavehei SM, Khani Jeihooni A, Hasanzadeh A, Amini S. The effect of educational program based on BASNEF model for eye care in non-insulin dependent diabetic patients. J Res Health Sci 2010; 10:81-90.

37. Dehdari T, Heydarnia AR, Ramezankhani A. Designing and implementing an interventional education program to improvement patients quality of life after CABG based on PRECEDE model. Journal of Birjand University of Medical Sciences 2008; 15:27-34.
38. Khani Jeihooni A, Kashfi SM, Zareei S, Kashfi $\mathrm{SH}$. Effectiveness of a training program based in PRECEDE model on fruit and vegetable consumption among female students. Int J Pediatr 2017; 5:5935-44.

39. Darvishpoor K, Heshmati H. Evaluation of nurses' knowledge, attitude, and performance in cardiopulmonary resuscitation (CPR) based on PRECEDE model. Cardiovascular Nursing Journal 2016; 5:18-25.

40. Kohzadi K. The effect of educationthrough BASNEF model on knowledge, attitude and practice of secondary schoolfirst year students in Baneh city about oral health. Tehran: Tehran University of Medical Sciences; 2008.

41. Hazavehei SH, Hasanzadeh A. The effect of volunteer health workers educational program on the basis of BASNEF model on promotion of their practices about Cutaneous. Zahedan Journal of Resarch in Medical Scice 2014; 16:16-21.

42. Daboné C, Delisle H, Receveur O. Predisposing, facilitating and reinforcing factors of healthy and unhealthy food consumption in schoolchildren: a study in Ouagadougou, Burkina Faso. Glob Health Promot 2013; 20:68-77. 


\section{Resumo}

A leishmaniose cutânea é endêmica no Irã. Devido ao importante papel da educação na prevenção de doenças, o estudo buscou medir o efeito de uma intervenção educacional, com base no modelo PRECEDE-PROCEED, sobre comportamentos preventivos contra a leishmaniose cutânea entre donas de casa iranianas. O estudo quasi-experimental incluiu 240 donas de casa matriculadas em centros de saúde em Mianshahr, na cidade de Fasa, uma área endêmica para leishmaniose cutânea no Irã. A amostra era constituída de 120 mulheres no grupo da intervenção e 120 no grupo controle. A intervenção educacional no grupo experimental teve como base o modelo PRECEDE, com sete sessões de 50-60 minutos cada, incluindo palestras, discussões em grupo, representação de papéis e atividades práticas, além de vídeos e apresentações em PowerPoint. As sessões destacaram a familiaridade com a leishmaniose cutânea es diferentes tipos, vetores e reservatórios, métodos de prevenção e de combate à doença, proteção individual, saneamento ambiental e da água, borrifação de criadouros, uso de mosquiteiros, etc. Os dados foram coletados antes e três meses depois da intervenção educacional. A média de idade do grupo experimental foi 39,24士9,12 anos, comparada com $38,84 \pm 9,28$ anos no grupo controle. Comparado ao grupo controle, três meses depois da intervenção o grupo experimental mostrou um aumento significativo no conhecimento, atitudes e fatores de reforço, facilitadores e de desempenho. A intervenção calcada nos fatores facilitadores, de reforço e predisponentes teve um efeito significativo sobre os comportamentos de prevenção da leishmaniose cutânea nesse grupo de mulheres iranianas.

Leishmaniose; Educação em Saúde; Prevenção de Doenças

\section{Resumen}

La leishmaniasis es endémica en Irán. Debido a la importancia de la educación en la prevención de la enfermedad, este estudio tuvo con meta determinar el efecto de la intervención educacional, basada en el modelo PRECEDE-PROCEED, sobre las conductas de prevención de la leishmaniasis cutánea entre amas de casa. En este estudio casi experimental, en 2016 se seleccionaron a 240 amas de casa dentro del ámbito de cobertura de centros de salud y residentes en el área endémica de Mianshahr, ciudad Fasa, provincia de Fars, Irán (120 personas se seleccionaron como grupo experimental y 120 como grupo de control). La intervención educacional para el grupo experimental se realizó basándose en el modelo PRECEDE, que consistió en siete sesiones de 50-60 minutos de clase, discusiones de grupo, ejercicios de dramatización $y$ presentaciones prácticas, así como de vídeo y PowerPoint. Estas sesiones con amas de casa trataron sobre la familiaridad con la leishmaniasis cutánea y sus diferentes tipos, sus portadores, métodos de prevención y combate contra la leishmaniasis cutánea, protección personal, saneamiento del medioambiente y agua potable, fumigación de focos, uso de mosquiteras, etc. Los datos se recogieron antes de la intervención educacional y 3 meses después de la intervención educacional. La edad media del grupo experimental era 39,24 9, 12años

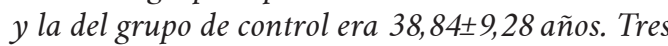
meses después de la intervención, el grupo experimental mostró un incremento significativo en el conocimiento, actitud, factores de refuerzo, factores propiciatorios y de rendimiento, comparado con el grupo de control. La educación basada en los factores propiciatorios, factores de refuerzo y de predisposición tuvo un efecto significativo en los comportamientos preventivos de la leishmaniasis cutánea entre amas de casa.

Leishmaniasis; Educación en Salud; Prevención de Enfermedades
Submitted on 13/Aug/2018

Final version resubmitted on 15/Dec/2018 Approved on 06/Feb/2019 